\title{
UM ESTUDO SOBRE O FENÔMENO DA INTERPOLAÇÃO DE CONSTITUINTES NA HISTÓRIA DO PORTUGUẾS ${ }^{1}$
}

\author{
CRISTIANE NAMIUTI TEMPONI \\ (IEL - UNICAMP)
}

\begin{abstract}
This paper presents and discusses the so-called phenomenon of interpolation in texts of Portuguese authors born among $16^{\text {th }}$ - $18^{\text {th }}$ century. In comparison with this phenomenon in Old Portuguese $\left(13^{\text {th }}\right.$ century to $16^{\text {th }}$ century), we show that the phenomenon extends to new contexts, but is restricted to the interpolation of negation.
\end{abstract}

A interpolação de constituintes entre o clítico e o verbo (ex.: que as ao dicto Monsteiro deuiã Alg uas pessoas. Lx, 1357 - Martins, 1994:175) é um fenômeno freqüente no Português antigo (doravante PA) e torna-se obsoleto no português europeu moderno (doravante PE).

Este fenômeno da não adjacência entre o clítico e o verbo foi um dos assuntos tratados por Ana Maria Martins 1994, em sua tese de doutoramento Clíticos na História do Português, com base num corpus de documentos notariais do PA (séculos 13 ao 16) editados pela própria autora. Os dados de Martins atestam uma preferência à interpolação do advérbio de negação "não", pois ocorre em número mais elevado do que os outros casos. No entanto, no PA, há um grande leque de elementos que podem ocorrer interpolados (qualquer constituinte que pudesse ocupar na oração uma posição pré-verbal podia ocorrer interpolado entre o clítico e o verbo).

No Corpus anotado do português histórico Tycho Brahe ${ }^{2}$ - utilizado na pesquisa - o advérbio de negação "não" é freqüentemente interpolado, porém, a interpolação de outros constituintes muito raramente se atesta e limita-se aos autores nascidos até a primeira metade do século 17.

O presente artigo tem como tarefa descrever o fenômeno da interpolação nestes textos representativos de um português intermediário entre PAe PE que chamaremos de português

\footnotetext{
${ }^{1}$ Resultados da pesquisa financiada pela FAFPESP (processos: 99/09712-4, 01/11285-9 e 04/01557-0 respectivamente iniciação cientifica, Mestrado transformado em Doutorado Direto), orientada por Charlotte M. C. Galves e realizada no âmbito do projeto temático Padrões Rítmicos Fixação de Parâmetros e Mudança Lingüística (fapesp: 98/3382-0 e 03/06822-0).

${ }^{2}$ Corpus eletrônico desenvolvido no âmbito do projeto temático Padrões Rítimicos Fixação de Parâmetros e Mudança Lingüística (fapesp: 98/3382-0) e exposto na internet no endereço http://www.ime.usp.br/tycho/ corpus
} 
NAMIUTI - Um estudo sobre o fenômeno da interpolação...

médio $^{3}$ (PM). Primeiramente, descreveremos brevemente os elementos que podiam ocorrer interpolados no PA e no PM, e em seguida trataremos dos contextos sintáticos nos quais este fenômeno podia ser realizado. Notaremos que: os elementos interpolados e os contextos em que são interpolados não são os mesmos nos dois períodos de que tratamos podendo assim indicar uma mudança sintática que afeta a colocação de clíticos, em especial o fenômeno da interpolação.

\section{OS CONSTITUINTES INTERPOLADOS}

Martins (1994) atesta que existia uma variação no uso da interpolação e da próclise no Português antigo, sendo que as primeiras sempre podiam ocorrer em contextos de próclise obrigatória, sendo até preferidas. Identifica os constituintes interpoláveis e observa em que tipo de orações a interpolação era possível. Em seu corpus qualquer elemento que pudesse ocupar na oração uma posição pré verbal poderia ocorrer interpolado:

a) o advérbio de negação: “(1) que me nom n ebram (NO, 1268)” (vide Martins, p. 162. 1994)

b) o sujeito: “(163) Isto que lhes eu mãdo (NO, 1275)" (vide Martins, p. 171. 1994)

c) um sintagma preposicional: “(108) asi como a atá áqui derõ (NO, 1295)” (vide Martins, p. 167. 1994)

d) um sintagma adverbial: "(64) quando uos ora fez merçee (NO, 1342)” (vide Martins, p. 165. 1994)

e) o objeto direto: "(223) que diga lhj eu alguma cousa diuia (NO, 1275)" (vide Martins, p. 174. 1994)

f) objeto indireto: “(232) que as ao dicto Monsteiro deuiã Alg uas pessoas (Lx, 1357)” (vide Martins, p. 175. 1994)

g) um núcleo predicativo de natureza adjetival: “(235) de todollos adubyos que lhes compridoiros $e$ neçesareos forem (Lx, 1476)" (vide Martins, p. 175. 1994)

h) um particípio passado: "(244) que lhys Assi escambhados Auyã (Lx, 1383)” (vide Martins, p. 175. 1994)

i) o infinitivo: “(246) e sse os dar nõ quysser (Lx, 1292)" (vide Martins, p. 177. 1994)

j) mais de um constituinte: “(263) quanto as eu mays pudj u ender (NO, 1277)” (vide Martins, p. 179. 1994)

1) um constituinte de redobro do clítico: “(258) asi como les a elles semellaua” (vide Martins, p. 178. 1994)

m) um quantificador: "(260) E prometo a m y tabaliam (...) de lho todo comprir e manther (LX, 1532)" (vide Martins, p. 178. 1994)

n) um vocativo: “(261) pois vo-l' eu, senhor, non mereci.” (vide Martins, p. 178. 1994)

o) uma oração reduzida: “(262) dos sobredictos autos que se pressente m j tabaliam pasarã (Lx, 1472)" (vide Martins, p. 178. 1994)

\footnotetext{
${ }^{3}$ Com base em Galves (2004), Paixão de Sousa (2004) considera que uma só gramática subjaz aos textos escritos entre 1400-1700: O Português Médio. Segundo a autora, esta gramática corresponde à escrita medieval (na sua etapa final), à escrita renascentista e à escrita barroca. Galves, Namiuti e Paixão de Sousa (2005) corroboram a hipótese do PM e apresentam os padrões de ordem que revelam a gramática média. "Um dos pontos em que este casamento entre a visão gerativista e a abordagem histórica se revela é na delimitação de fases históricas ou periodização da história das línguas. Nosso desafio, neste respeito, foi realizar um caminho de mão-dupla. De um lado, partimos do patrimônio de conhecimento acumulado pela tradição dos estudos históricos sobre a língua portuguesa. De outro lado, buscamos reinterpretar essa tradição, à luz da reflexão propiciada pelo conceito de Gramática Internalizada, e das consequências desse contexto na investigação das mudanças. Neste percurso, revisitamos a periodização da Língua Portuguesa; e sugerimos hoje uma nova divisão em etapas históricas, que se fundamenta nos resultados da análise exaustiva de padrões sintáticos a partir de nosso levantamento de dados. Este levantamento foi realizado junto a um conjunto de textos escritos por autores portugueses nascidos entre os séculos 16 e 19, reunidos no Corpus Tycho Brahe.”.
} 
Este quadro mudou no PM, onde as ocorrências dos diversos elementos interpolados se reduziram a praticamente um caso de interpolação: a do advérbio de negação - "não". Alguns elementos particularmente freqüentes quanto elementos interpolados no PA ainda aparecem interpostos entre o clítico e o verbo até o século 17, porém com baixa frequiência. São estes elementos: pronomes e NPs (Noun Phrase) sujeitos, QPs (Quantificational Phrase) , PPs (Prepositinal Phrase) e alguns advérbios. Os dados de interpolação generalizada foram atestados em 5 textos de autores nascidos na segunda metade do século 16 e primeira metade do século 17 , com aproximadamente 50.000 palavras cada texto e $8.782^{4}$ cliticos pré-verbais, e estão distribuídos da seguinte maneira: registra-se interpolados: 45 sujeitos, 6 PPs, 5 advérbios, 1 sintagma quantificado (QP), e 3 dados com mais de um elemento interpolado (sendo 2 casos com o sujeito e a negação entre o clítico e o verbo). Os exemplos abaixo ilustram esses casos.

1. Isto lhe disse de todo seu ânimo ; e certo que se lhe ElRei não mandára sucessor , que o houvera de fazer , porque era um Fidalgo muito determinado. (Couto_1542)

2. Cortesãmente me tratam ; porque algumas horas que se ocupam, me tem respeito : são vivos e meus parentes muito chegados ; baste a dano que lhe eu faço. (Chagas_1651)

3. - É tão saborosa a murmuração de Solino ( disse Leonardo ) que também na mesa se pode estimar como boa iguaria ; e , se a $e u$ tiver a muitas vezes, dera vida ao apetite que para as outras me falta . (Lobo_1579)

4. Dando graças a um sujeito, pela inclinação que lhe mostrava sem conhecê-lo Dizem lá que onde me a $m i$ conhecem, honra me fazem. (Melo_1608)

5. Entre os pobres, sobre todos, tenha cuidado dos doentes, que não podem andar pedindo, como lhe muitas vezes disse. (Sousa_1556)

6. Não é menos o que me lá anda neste infelíssimo jôgo . (Melo_1608)

7. Achando-se Vossa Mercê com novas do ausente , para Vossa Mercê das que souber comigo ; que só o frade ( e não o clérigo , e menos o amigo professo ) não dá do que lhe bem sabe . (Melo_1608)

8. Coge Çofar, que na Corte tinha o primeiro lugar, vendo ElRei com tamanha tristeza, e melancolia , se foi a ele estando com alguns Capitães principaes, e lhe pedio licença pera lhe dizer algumas cousas , que cumpriam a seu serviço ; e dando-lha êle, posto em pé, lhe fez esta fala : "A cousa, de que me hoje mais glorio, muito Grande , e Poderoso Rei , é de se ter visto em mim , depois que vim a êstes Reinos ... . (Couto_1542)

9. Também ( disse o Doutor ) houve já neste Reino escravos ilustres , de muito valor , entendimento e sangue, conhecidos por tais e tratados como se estivessem em liberdade, que cativaram nas nossas fronteiras de África, em cujas histórias me eu não quero deter por me não alongar mais do intento do nosso discurso dos recadistas ,.... . (Lobo_1579)

Os Quadros I e II de Martins (1994:193), reproduzidos abaixo, já indicam para a interpolação de elementos diferentes de não um início de um processo de mudança a partir do século 15: a frequiência de interpolação de elementos diferentes da negação começa a diminuir e a escolha sem interpolação começa a ser mais usada. Mas a frequiência de interpolação da negação é sempre muito superior à dos demais constituintes interpoláveis (valores próximos a 100\%) e isto, para Martins, indica que a interpolação de 'não' tem uma história própria.

\footnotetext{
${ }^{4}$ Diogo do Couto, Frei Luís de Sousa, Francisco Rodrigues Lobo, Francisco Manuel de Melo e António das Chagas são os autores que ainda atestam a interpolação de elementos diferentes da negação. No entanto estes autores têm respectivamente em seus textos 1.666, 1.353, 1.773, 2.030, 1.960 clíticos pré-verbais e apenas $38,3,8,9$ e 2 desses casos têm algum elemento diferente da negação interpolado.
} 
NAMIUTI - Um estudo sobre o fenômeno da interpolação...

\section{Quadro I - Interpolação de elementos diferentes de não}

\begin{tabular}{|c|c|c|c|c|}
\hline & $\begin{array}{c}\text { Sécub } \\
\text { XIII }\end{array}$ & $\begin{array}{c}\text { Sécub } \\
\text { XIV }\end{array}$ & $\begin{array}{c}\text { Sécub } \\
\text { XV }\end{array}$ & $\begin{array}{c}\text { Sécub } \\
\text { XVI }\end{array}$ \\
\hline Interpo lação atualizada & $\begin{array}{c}26 / 39 \\
(66,6 \%)\end{array}$ & $\begin{array}{c}78 / 13 \\
(69,1 \%)\end{array}$ & $\begin{array}{c}70 / 123 \\
(57 \%)\end{array}$ & $\begin{array}{c}62 / 120 \\
(51,7 \%)\end{array}$ \\
\hline $\begin{array}{c}\text { C litio adjacoente ao } \\
\text { verbo em estruturas de } \\
\text { potencílinterpolação }\end{array}$ & $\begin{array}{c}13 / 39 \\
(33,3 \%)\end{array}$ & $\begin{array}{c}35 / 113 \\
(30,9 \%)\end{array}$ & $\begin{array}{c}53 / 123 \\
(43 \%)\end{array}$ & $\begin{array}{l}58 / 120 \\
(48,3 \%)\end{array}$ \\
\hline
\end{tabular}

\section{Quadro II - Interpolação de não}

\begin{tabular}{|c|c|c|c|c|}
\hline & $\begin{array}{l}\text { Sécub } \\
\text { X IIII }\end{array}$ & $\begin{array}{l}\text { Sécub } \\
\text { XIV }\end{array}$ & $\begin{array}{l}\text { Sécub } \\
\text { XV }\end{array}$ & $\begin{array}{l}\text { Sécub } \\
\text { XVI }\end{array}$ \\
\hline Interpo lação atualizada & $\begin{array}{l}16 / 17 \\
(94,1 \%)\end{array}$ & $\begin{array}{c}30 ß 1 \\
(96,8 \%)\end{array}$ & $\begin{array}{l}13 / 14 \\
(90,7 \%)\end{array}$ & $\begin{array}{l}18 / 20 \\
(90 \%)\end{array}$ \\
\hline $\begin{array}{l}\text { C litico adjacente ao } \\
\text { verbo em estruturas de } \\
\text { potencial interpolação }\end{array}$ & $\begin{array}{l}1 / 17 \\
(5,9 \%)\end{array}$ & $\begin{array}{c}1 \beta 1 \\
(3,2 \%)\end{array}$ & $\begin{array}{l}1 / 14 \\
(9,3 \%)\end{array}$ & $\begin{array}{l}2 / 20 \\
(10 \%)\end{array}$ \\
\hline
\end{tabular}

Para o PM, os textos do Corpus Tycho Brahe ${ }^{5}$ vem comprovar o uso bastante freqüente e até preferido da interpolação da negação até o século 19 e o desuso da interpolação de outros constituintes.

${ }^{5}$ Cabe notar que existem duas diferenças quanto às datas consideradas nos 2 corpora (o de documentos notariais e o corpus Tycho Brahe). A primeira é quanto o agrupamento: enquanto Martins (1994) agrupa os textos por século, nós agrupamos por autor. A segunda é quantop a data considerada: Martins (1994) se refere à data de produção dos textos, pois é esta a que se tem acesso, nós adotamos como referência a data de nascimento dos autores. Sendo assim, há uma defasagem na comparação entre os dois corpora de mais ou menos 50 anos. 
Quadro III- A posição do clítico em sentenças dependentes afirmativas: a estrutura “conjunção-cl-X-V” versus a estrutura "conjunção- $X-c l-V$ ”no Corpus Tycho Brahe.

\begin{tabular}{|c|c|c|c|c|c|c|c|c|c|c|c|c|c|c|c|c|c|}
\hline Sécula & \multicolumn{3}{|c|}{$X V I$} & \multicolumn{7}{|c|}{ XVII } & \multicolumn{4}{|c|}{ XV III } & \multicolumn{2}{|l|}{$X I X$} & \multirow{2}{*}{$\begin{array}{c}\text { Total } \\
\ldots \ldots \ldots . . .\end{array}$} \\
\hline Autores & $\mathrm{Cou}$ & Sou & Lob & $\mathrm{M} \mathrm{el}$ & $V \dot{e}-C$ & Vie-s & Chag & Bem & Bro & $\mathrm{a}-\mathrm{Bar}$ & $A$ ir & Vem & Garc & $A b$ & Gatt & O rt & \\
\hline $\begin{array}{l}\text { D ata de } \\
\text { N ascinento }\end{array}$ & 1542 & 1556 & 1579 & 1608 & 1608 & 1608 & 1631 & 1644 & 1651 & 1675 & 1705 & 1713 & 1724 & 1750 & 1799 & 1836 & C onpus \\
\hline clneg-vb & 93 & 53 & 98 & 139 & 158 & 103 & 131 & 67 & 28 & 26 & 97 & 35 & 32 & 64 & 81 & 38 & 1243 \\
\hline $\mathrm{N}$ eg-Cl-rb & 16 & 34 & 31 & 33 & 53 & 60 & 64 & 50 & 12 & 17 & 109 & 116 & 23 & 40 & 37 & 19 & 714 \\
\hline Total & 109 & 87 & 129 & 172 & 211 & 163 & 195 & 117 & 40 & 43 & 206 & 151 & 55 & 104 & 118 & 57 & 1957 \\
\hline $\begin{array}{l}\text { Freqüêncí de } \\
\text { Interpolação }\end{array}$ & 0,85 & 0,61 & 0,76 & 0,81 & 0,75 & 0,63 & 0,67 & 0,57 & 0,70 & 0,60 & 0,47 & 0,23 & 0,58 & 0,62 & 0,69 & 0,67 & 0,63 \\
\hline $\begin{array}{l}\text { Frequiência de } \\
\text { Próclise }\end{array}$ & 0,15 & 0,39 & 0,24 & 0,19 & 0,25 & 0,37 & 0,33 & 0,43 & 0,30 & 0,40 & 0,53 & 0,77 & 0,42 & 0,38 & 0,31 & 0,33 & 0,37 \\
\hline
\end{tabular}


Quadro IV - A posição do clítico em sentenças negativas: a estrutura "cl-neg-V" versus a estrutura "neg-cl-V" no Corpus Tycho Brahe

\begin{tabular}{|c|c|c|c|c|c|c|c|c|c|c|c|c|c|c|c|c|c|}
\hline Século & \multicolumn{3}{|c|}{$X V I$} & \multicolumn{7}{|c|}{$X V I I$} & \multicolumn{4}{|c|}{ XV III } & \multicolumn{2}{|l|}{$X \mathbb{X}$} & Total \\
\hline Autores & $\mathrm{Cou}$ & Sou & Lob & $\mathrm{M}$ el & $\mathrm{Vie}-\mathrm{C}$ & Vie-s & Chag & Bem & Bro & $a-B a r$ & $A$ ir & Vem & Garc & $A b$ & Gatt & O it & …............ \\
\hline $\begin{array}{l}\text { Data de } \\
\text { N ascin ento } \\
\text { Conj'clX -rb }\end{array}$ & $\begin{array}{l}1542 \\
26\end{array}$ & $\begin{array}{l}1556 \\
3\end{array}$ & $\begin{array}{l}1579 \\
7\end{array}$ & $\begin{array}{l}1608 \\
9\end{array}$ & $\begin{array}{l}1608 \\
0\end{array}$ & $\begin{array}{l}1608 \\
0\end{array}$ & $\begin{array}{l}1631 \\
2\end{array}$ & $\begin{array}{l}1644 \\
0\end{array}$ & $\begin{array}{l}1651 \\
0\end{array}$ & $\begin{array}{l}1675 \\
0\end{array}$ & $\begin{array}{l}1705 \\
0\end{array}$ & $\begin{array}{l}1713 \\
0\end{array}$ & $\begin{array}{l}1724 \\
0\end{array}$ & $\begin{array}{l}1750 \\
0\end{array}$ & $\begin{array}{l}1799 \\
12\end{array}$ & $\begin{array}{l}1836 \\
0\end{array}$ & $\begin{array}{l}\text { C onpus } \\
47\end{array}$ \\
\hline ConjX-clvb & 229 & 308 & 416 & 586 & 387 & 595 & 472 & 446 & 234 & 295 & 641 & 446 & 159 & 385 & 247 & 168 & 4132 \\
\hline Total & 255 & 311 & 423 & 595 & 387 & 595 & 474 & 446 & 234 & 295 & 641 & 446 & 159 & 385 & 259 & 168 & 4179 \\
\hline $\begin{array}{l}\text { Freqüência de } \\
\text { Interpolação }\end{array}$ & 0,10 & 0,01 & 0,02 & 0,02 & 0,00 & 0,00 & 0,004 & 0,00 & 0,00 & 0,00 & 0,00 & 0,00 & 0,00 & 0,00 & 0,05 & 0,00 & 0,01 \\
\hline $\begin{array}{l}\text { Freqüêencia de } \\
\text { Próclise }\end{array}$ & 0,90 & 0,99 & 0,98 & 0,98 & 1,00 & 1,00 & 0,996 & 1,00 & 1,00 & 1,00 & 1,00 & 1,00 & 1,00 & 1,00 & 0,95 & 1,00 & 0,99 \\
\hline
\end{tabular}




\section{OS CONTEXTOS SINTÁTICOS EM QUE A INTERPOLAÇÃO SE REGISTRA NA HISTÓRIA DO PORTUGUÊS}

\subsection{A interpolação da negação e dos demais constituintes no PA e no PM}

Martins (1994) (cf. também Parcero 1999, Fiéis 2000, entre outros) atestou que existia uma variação entre a adjacência do clítico ao verbo e a interpolação de constituintes nas sentenças de próclise no português antigo (PA). Esta variação se dá apenas em contexto de anteposição verbal obrigatória do clítico (contextos de subordinação e em oração matrizes introduzidas por operadores "proclisadores"), preferindo este estar adjacente ao operador. E quando um constituinte capaz de provocar anteposição obrigatória do clítico está ele próprio interpolado, como é o caso da negação, outro "operador proclisador" deve introduzir a oração para que a interpolação seja possível.

a) que me nom n ebram (NO, 1268) (Martins, 1994:189)

b) o quall casal the asi emprazou (NO, 1513) (Martins, 1994:189)

No entanto, verifico nos textos literários representantes dos séculos 16, 17 e 18 que, juntamente com a perda da interpolação dos constituintes do sintagma verbal, surgem novas possibilidades de interpolar a negação: encontra-se o "não" interpolado não só em contextos onde há a presença de um operador que condicione a próclise, mas também em contextos sem operadores "proclisadores": orações matrizes e coordenadas raízes ${ }^{6}$ introduzidas por: sujeitos pronominais, nominais simples e complexos (como nos exs.: 10, 11, 12, 13, 14, 15, e 16); PPs (ex.: 17); orações (ex.: 18), mais de um constituinte (exs.: 19 - sujeito + oração - e 20 - oração + sujeito) e alguns casos em coordenadas V1 (ex.: 21):

10. $<\mathrm{P} \_161>$ Dom Manoel de Lima o não quiz ouvir naquele negócio, dizendo-lhe, que era filho mais velho de seu pai, que se queria ir pera o Reino, e que quando lhe ElRei não desse de comer, que viveria com o que seu pai viveo. (Couto - 1542)

11. Ainda bem as árvores não dão seu fruto , quando vossos criados mo trazem; e do que até nos agros se sente a falta, eu a não tenho. (Lobo-1579)

12. Essa é muito larga (disse o Prior) e são passadas muitas horas da noite; e eu me não escusara com elas se não imaginara que tôdas as verdades, que caiem sôbre êste sujeito, hão-de parecer murmuração . (Lobo-1579)

13. Meu desejo se não estende a mais que a alcançar me mudem de prisão a prisão, e não dela para a liberdade (Melo-1608)

14. "João de Guimarães se não carteia com esta embaixada há muitos correios/, (...)" (Vieira_cartas - 1608)

15. Às vezes a quero negar e os companheiros me não deixam. (Chagas-1631)

16. E , como cá dizemos que quem o Demo toma uma vez, sempre lhe fica um geito, eu o não perdi nem por haver perdido tudo quanto tinha e quanto podia esperar. (Melo- 1608)

17. Eis-aqui como este prelado julgava aquela causa de sua breve ausência por justificada com o título de necessidade urgente e, na verdade, o não era no juízo de um príncipe pio e prudente e que via as coisas de perto boa intenção. (Bernardes-1644)

18. $\mathrm{E}$, chegando a alguma que com menos apêrto faça sua relação, me não pareceu enjeitar a que Marcelo escreveu ao Senado Romano, dando-lhe novas da derrota de Fúlvio, que dizia: "Bem sei que a nova, que vos mando , é de sentimento. (Lobo-1579)

\footnotetext{
${ }^{6}$ Orações não dependentes neutras, segundo a terminologia de Martins 1994.
} 
NAMIUTI - Um estudo sobre o fenômeno da interpolação...

19. Que havia de ser de Agostinho, de quem se rezava nas escolas catholicas: A logica Augustini libera nos Domine; se amollecido com as lagrimas de sua mãe, ella (como um lyrio que se gera das lagrimas de outro). o não tornara a gerar? (Vieira-Sermões-1608)

20. Ao outro dia pôs em execução êste pensamento, e, deixando para seu tempo o sucesso que teve, os da conversação o não souberam todo aquêle dia; e, quando veio a noite, que o acharam menos, houve quem desse novas de como o encontrara naquela emprêsa; e com esta ocasião começaram a prática, e disse o Doutor: - Sempre ouvi que os cuidados de amor em peitos generosos saiem com seus extremos ao longe , e que então se forçam quando os outros sujeitos desconfiam. (Lobo-1579)

21. E porque os próprios papeis, que sôbre isto se fizeram, ou são levados pera o Reino, ou perdidos, ficou isto fazendo confusão, e o não podemos averiguar, senão pelo Regimento daquela fortaleza ... (Couto - 1542)

Os contextos em que ocorrem interpolados elementos diferentes da negação nos textos representantes do PM são, na maioria dos dados atestados, os mesmos contextos atestados por Martins para o PA. Porém, foram atestados 2 casos de sujeitos interpolados em contexto de variação no posicionamento dos clíticos. O primeiro, no século 17, é um dado de Francisco Manuel de Melo em uma oração matriz introduzida por uma oração subordinada (um caso de oração não dependente neutra). Já o segundo foi atestado no século 19, um pronome sujeito interpolado em uma oração gerundiva ${ }^{7}$ por Almeida Garrett. Uma vez que a interpolação de constituintes diferentes da negação desaparece por completo dos textos no século 17, podemos admitir, assumindo a teoria de mudança e competição de gramáticas de Kroch $(1989,2003)$, que a interpolação atestada nos textos a partir do século 16 é o reflexo de uma competição de gramáticas, a ordem linear "conjunção - clítico - elementos do predicado - verbo" seria característica da gramática mais antiga (PA). Então quando estes autores no século 17, e mais ainda no 19, usam a interpolação, estão escrevendo como os antigos e é por não conviverem mais com tal gramática que produzem dados como os exemplificados abaixo.

22. Se em tudo isto tenho que pedir a Vossa Mercê seu favor, o Vossa Mercê sabe ; se o devo esperar, eu o sei.

23. Em lhe $e u$ dizendo quem tu és e a que cá vens, ele sabe o estado de minha avó, e tem-lhe muita amizade, dános decerto licença para tu vires em toda a segurança. (Garrett-XIX)

\subsection{A INTERPOLAÇÃO DA NEGAÇÃO NO PM - DESCRIÇÃO QUALITATIVA}

\subsubsection{Em orações dependentes finitas: subordinadas e coordenadas (semelhanças com o PA)}

Orações subordinadas finitas já formavam um contexto de potencial interpolação no PA, como atesta Martins 1994, e este é também o contexto em que mais se encontra a negação interpolada no PM, sendo ainda as sequiências com interpolações preferidas às sequiências com o clítico adjacente ao verbo, como podemos constatar no quadro abaixo.

\footnotetext{
${ }^{7}$ Orações gerundivas nunca foram contexto de interpolação em português.
} 


\begin{tabular}{|c|c|c|c|c|c|c|c|c|c|c|c|c|c|c|c|c|}
\hline & Couto & Sousa & Lobo & M eb & $\mathrm{V}$ éc & Vies & Chag & $\mathrm{Bem}$ & Broch & A $B a r$ & A res & Vem & Garc & A br & Gatt & Ortig \\
\hline Data & 1542 & 1556 & 1579 & 1608 & 1608 & 1608 & 1631 & 1644 & 1651 & 1675 & 1705 & 1713 & 1724 & 1750 & 1799 & 1836 \\
\hline \multirow{2}{*}{$\begin{array}{l}C \text { lneg-V } \\
N \text { eg-cl-v }\end{array}$} & 56 & 42 & 64 & 96 & 113 & 79 & 95 & 48 & 32 & 19 & 76 & 27 & 19 & 53 & 55 & 42 \\
\hline & 4 & 14 & 9 & 0 & 22 & 4 & 11 & 19 & 8 & 3 & 17 & 0 & 0 & 10 & 1 & 2 \\
\hline \multirow{2}{*}{$\begin{array}{l}\text { Total } \\
\text { Frequiência de } \\
\text { Intenpoolicãão }\end{array}$} & 60 & 56 & 73 & 96 & 135 & 83 & 106 & 67 & 40 & 22 & 93 & 27 & 19 & 63 & 56 & 44 \\
\hline & 0,93 & 0,75 & 0,88 & 1,00 & 0,84 & 0,95 & 0,90 & 0,72 & 0,80 & 0,86 & 0,82 & 1,00 & 1,00 & 0,84 & 0,98 & 0,95 \\
\hline $\begin{array}{l}\text { Freqüuência } \\
\text { de próclise }\end{array}$ & 0,07 & 0,25 & 0,12 & 0,00 & 0,16 & 0,05 & 0,10 & 0,28 & 0,20 & 0,14 & 0,18 & 0,00 & 0,00 & 0,16 & 0,02 & 0,05 \\
\hline
\end{tabular}


NAMIUTI - Um estudo sobre o fenômeno da interpolação...

24. ... porque aquele lugar que se não desocupou do sofrimento jámais, mal poderia receber a desesperação agora. (Melo_1608)

25.... (diz o Apostolo) pois empregae todo o vosso cuidado em Deus, como se o não fôreis. (Vieira-cartas_1608)

26. Quando se $n \tilde{a} o$ pode negar o ajuste nega-se-lhe o sentido; ... (Aires_1705)

27. ... e obrigado a saber se visitam eles os doentes e, se o não fizerem, sobre mim cai seu descuido ... (Sousa_1656)

28. Já que me não ouvem, que me leiam vocês. (Ortigão_1836)

As orações coordenadas a uma subordinada também apresentam interpolação da negação no PM. Quando a conjunção "e" liga uma série de subordinadas a uma única oração principal sem que haja a repetição da conjunção subordinativa, do pronome relativo ou do complementador, Martins (1994) observa que no PA pode ocorrer interpolação em qualquer membro da série ...

"em estruturas em que uma série de subordinadas estão ligadas entre si por coordenação dependem de uma única oração principal, não havendo repetição do complementador, a interpolação é possível em qualquer dos membros da série. Isto é a interpolação pode ocorrer não só na primeira das orações subordinadas (aquela em que a posição do Comp está lexicalmente preenchida) mas também nas que se ligam por coordenação." (Martins, 1994:184)

\section{Alguns exemplos de interpolação nesse contexto no PM:}

29. "Porque poderoso que possa quebrar as leis, e as não quebra: ..." (Vieira-sermões - XVII)

30. E assim será sempre que eu possa, ou o não impida impulso do Espírito Santo. (Chagas - XVII)

31. E assim não me desagradou outra, que dizia desta maneira: "Com os tempos contrários à navegação o foram as ocasiões ao nosso trato; que, como as mercadorias não foram requestadas de estrangeiros, estão ao presente abatidas; enviai-me menos delas para que, faltando, mais as procurem os mercadores da terra; $\underline{\mathrm{e}}$ nessa vos não descuideis de fazer emprêgo, mandando-me o de muito boas novas vossas". (LOBO - XVI)

A omissão do complementador nas orações subordinadas completivas é freqüentemente atestada nos textos dos autores nascidos nos séculos 16 e 17. Também foi registrada a interpolação da negação em orações completivas com o complementador nulo nos textos deste período.

Seguem-se três exemplos:

32. "Parece _ o não deve negar a Piedade e a Cristandade" (Melo)

33. "Agora é o meu maior negócio pedir a Vossa Mercê _ se não esqueça de mi; e igualmente em me fazer mercê que em me mandar-lhe faça muitos serviços." (Melo)

34. “... e com o mesmo contentamento receberei todas as que me trouxerem boas novas de Vossa Excelência, com que peço a Vossa Excelência _ me não falte, ...” (Vieira_cartas)

Apesar da baixa freqüência, a estrutura não parece marginal, pois não se apresenta isoladamente em um autor, mas é atestada em 5 autores contemporâneos. Ou seja, a ocorrência deste tipo de estrutura está sendo atestada num intervalo contínuo de tempo

\footnotetext{
${ }^{8}$ Entende-se "complementador (Comp) na passagem de Martins como um conector subordinante, ou seja, um pronome relativo (WPRO), uma conjunção subordinativa (CONJS), ou ainda um 'que' complementizador (C)".
} 
Cadernos de Estudos Lingüísticos 48(2) - Jul./Dez. 2006

(autores nascidos na segunda metade do século 16 e primeira metade do século 17). Apresentando-se deste modo como um grupo coeso.

\subsubsection{A interpolação da negação no PM em orações infinitivas, coordenadas e não dependentes (semelhanças e diferenças do PA).}

Lembremo-nos que, segundo Martins (1994), os contextos de possível ocorrência de interpolação no PA são os de próclise obrigatória, tendo o clítico de ocorrer obrigatoriamente de maneira adjacente ao verbo nos contextos de próclise opcional.

\section{i) Orações infinitivas}

Martins atestou no seu corpus de documentos notariais que a interpolação em orações infinitivas poderia ocorrer desde que fosse introduzida por uma preposição que condicionasse próclise categórica, estando o clítico adjacente a esta preposição. Todavia atestei 2 casos de interpolação da negação nos textos literários do PM em orações infinitivas sem preposição:

35. "vendo que, por se não ajudar de suas riquezas, e as não despender em sôldo, não tivera resistência contra o exército dos Tártaros ," (Lobo - XVI)

36. "Que pelo pecado mortal não se perde esta imagem , ...., e porque as potências e actos da alma ( em que consistia também a dita razão de imagem ), empregando-se no pecado, buscam o não ser, pois o ser do pecado é nada e , por conseguinte , alongam-se de Deus, que é o mesmo ser ./. " (Bernardes -XVII)

O dado 35 tem o "não" interpolado em uma oração infinitiva coordenada a uma outra infinitiva, sendo que na segunda oração infinitiva a preposição "por" foi omitida. Podemos considerar que a interpolação na segunda oração infinitiva com a omissão da preposição é um efeito de paralelismo, pois na primeira das orações o "não" já aparece interpolado, e a segunda, que está ligada à primeira por coordenação, repete a mesma estrutura.

Já no dado 36 a negação aparece interpolada na oração com o verbo infinitivo que funciona como predicado do verbo finito - "buscam" - este é um contexto totalmente novo, porém isolado.

No corpus de Martins 1994, referente ao PA, as preposições que introduzem as orações com interpolação são "por", "pera", "de" e " $a$ ". Martins não atestou interpolação com "em" introduzindo a oração infinitiva, e, apesar de encontrar um caso no corpus de Ogando de documentos literários, não considera esta preposição um potencial desencadeador de interpolação, pois "em" usualmente desencadeia ênclise? .

Estudos sobre a posição dos clíticos em orações infinitivas apontam que certas preposições oscilam seu comportamento ao longo da diacronia do português. Algumas preposições que no PA ocasionavam categoricamente a próclise, no século 16 constituem ambientes de variação próclise $\mathrm{X}$ ênclise, como é o caso das preposições "para" e " $a$ " nos estudos de

\footnotetext{
${ }^{9}$ Segundo os estudiosos dos clíticos a preposição "em" sempre desencadeou ênclise em português, não havendo variação ao longo da história.
} 
NAMIUTI - Um estudo sobre o fenômeno da interpolação...

Ribeiro (1995), e mais recentemente os dados de Abdo (2000) mostram que além de "para" $e$ " $a$ ", também com a preposição "de" o pronome clítico está variando sua posição, proclítico ou enclítico ao verbo. Sendo assim, esperaríamos que o clítico estivesse sempre adjacente ao verbo. Entretanto, encontra-se nos textos do corpus Tycho Brahe a negação interpolada em orações infinitivas introduzidas pela preposição "em", e também pelas preposições, "para"/ "pera" $e$ "de"10 nos textos em que estas preposições apresentam flutuação "V-cl" "cl-V". A preposição "por" condiciona próclise invariavelmente na história do português e continua a desencadear interpolação da negação, por vezes o clítico se aglutina a ela formando "pelos/pelas, pólas/pólos ....".

37. "E sintido do mal, que o fizera com ele a infirmidade em o não enterrar," (Sousa - XVI)

38. "- Bem se representou em Midas (acrescentou Píndaro) um cobiçoso no pedir e em se não aproveitar;" (Lobo XVI)

39. Assi me tenho de todo resolvido em lhe não oferecer rogos, que a encruecem. (Melo - XVII)

40. "e assim veja Vossa Mercê quanto mal fará em me não advertir de tudo o que souber," (Chagas - XVII)

41. "a falta de Religião consiste em se não temer a Deus," (Aires - XVIII)

42. "lhe atava as mãos, pera se não quietar com nada, (Sousa - XVI)

43. Importa muito ter o texto correcto, para se não enganar neste particular." (Verney - XVIII)

44. “... . mas daí enquanto a saúde da Bertha não for perfeita é preciso que escreva sempre alguém para me não pôr em grandes cuidados." (Ortigão - XIX)

45. "peço perdão de me não aproveitar dêle." (Chagas - XVII)

46. "Sim, assentámos de lho não dizer a uma nem a outra até que tivéssemos certeza da tua melhora . (Garrett $\mathrm{XIX)}$

47. "Rodeo quando posso por vos não tratar de aquelas décimas do poeta noviço". (Vieira-sermões - XVII)

48. “... pelos não escrever logo. (Alorna -XVIII)

\section{ii) - Interpolação em orações não dependentes}

Como vimos, orações não dependentes neutras não formam contextos para a interpolação no PA. No entanto, o fenômeno da interpolação podia ocorrer em orações matrizes e coordenadas raízes no Corpus de Martins (PA) desde que introduzidas por um elemento que condicionasse próclise obrigatória: Um sintagma focalizado, um quantificador e certos advérbios. A interpolação neste ambiente continua a ser atestada no PM: No Corpus Tycho Brahe, os advérbios ainda/inda, também, já, quasi, assim, ADVRs (EX.: tanto) sempre desencadeiam a interpolação da negação. E os advérbios que apareceram antecedendo a sequiência com o ' $n a \tilde{o}$ ' não interpolado e o clítico adjacente ao verbo foram os advérbios que não condicionam próclise categórica, como 'hoje/ADV' e os terminados em '-mente'.

49. "Destas minhas mazelas já me não queixo." (MELO - XVII)

Entretanto, no PM, a interpolação de "não" tem um comportamento diferente da interpolação tradicional (descrita para o PA): Além de ser produtivamente atestada nas

${ }^{10}$ Não atestamos mais a interpolação da negação em orações infinitivas introduzidas pela preposição “ $a$ ". 
orações raízes, é possível encontrar interpolação da negação em orações não dependentes "neutras". Martins (1994) atestou alguns casos no final do século 15 e século 16.

Nas frases de número 325 a 328 do corpus de Martins há interpolação do advérbio de negação "não" em orações não dependentes, sem que nenhum quantificador, advérbio proclisador ou sintagma focalizado introduza a oração.

“(325) e durante ho "tenpo das ditas tres vidas lho nom possam tolher (NO, 1496)" (Martins, 1994:189)

“(326) e durante ho tempo das ditas tres vidas lho nom possam leixar nem engeitar (NO, 1505)" (Martins, 1994:189)

“(327) E nom pagãdo elles emprazadores e pessoa depos elles a dicta pemsam (...) que o dicto dom prior e seus ssobçessores os mãdem por ella penhorar em seus b ees moues e de raiz (...) e elles emprazadores lhes ñ̃ tolherã os penhores e nõ faram outro feu ne foro a outra nenh uma pessoa (NO, 1509)" (Martins, 1994:189)

"(328) e que nam pagando a dita Renda que possam ser penhorados em seus b ees e vendidos E arematados sem mandado e autorjdade de Justiça e se nam chamaram por ello forcados nem esbulhados (NO, 1522)" (Martins, 1994:189)

Martins pensa que, apesar da baixa freqüência deste tipo de exemplos, a estrutura por eles representada não deve ser considerada gramaticalmente marginal. Para ela há duas constantes que os fazem aparecer como um grupo coeso: todos são exemplos tardios (localizados cronologicamente em finais do século XV, século XVI) e em todos os casos o elemento interpolado é o "não".

Martins ainda admite que a limitação temporal referida faz pensar que alguma mudança sintática ocorreu, tornando possível um certo tipo de interpolação anteriormente não permitida. Porém, para ela, o fato de só o operador de negação predicativa ocorrer interpolado, nestas condições, parece indicar que o caráter peculiar das frases acima referidas só poderá ser explicado tendo em conta a sintaxe da negação.

No corpus Tycho Brahe ela é produtiva nos autores nascidos até meados do século 17. 
NAMIUTI - Um estudo sobre o fenômeno da interpolação...

Quadro VI - Interpolação da negação no Corpus Tycho Brahe em orações não dependente neutras de acordo com o constituinte inicial, se sujeito, PP ou oração, e o total de dados neste ambiente

\begin{tabular}{|c|c|c|c|c|c|c|c|c|c|c|c|c|c|c|c|c|c|}
\hline \multirow{2}{*}{$\begin{array}{r}\text { Século } \\
\text { Autores }\end{array}$} & & \multicolumn{3}{|c|}{ XVI } & \multicolumn{7}{|c|}{ XVII } & \multicolumn{4}{|c|}{ XVIII } & \multicolumn{2}{|l|}{ XIX } \\
\hline & & $\mathrm{Cou}$ & Sou & Lob & Mel & Vie-c & Vie-s & Chag & Bern & Bro & $\mathrm{a}-\mathrm{Bar}$ & Air & Vern & Garc & Alo & Gatt & Ortig \\
\hline Data & & 1542 & 1556 & 1579 & 1608 & 1608 & 1608 & 1631 & 1644 & 1651 & 1675 & 1705 & 1713 & 1724 & 1750 & 1799 & 1836 \\
\hline \multirow{4}{*}{ Sujeito } & Cl-neg-vb & 2 & 0 & 5 & 2 & 4 & 1 & 2 & 0 & 0 & 1 & 0 & 0 & 0 & 0 & 1 & 0 \\
\hline & Neg-cl.-vb & 4 & 2 & 3 & 4 & 3 & 6 & 11 & 2 & 1 & 3 & 55 & 12 & 3 & 11 & 12 & 5 \\
\hline & Total & 6 & 2 & 8 & 6 & 7 & 7 & 13 & 2 & 1 & 4 & 55 & 12 & 3 & 11 & 13 & 5 \\
\hline & $\%$ Interp. & 0,33 & 0 & 0,62 & 0,33 & 0,57 & 0,14 & 0,15 & 0 & 0 & 0,25 & 0 & 0 & 0 & 0 & 0,08 & 0 \\
\hline \multirow{4}{*}{ PP } & Cl-neg-vb & 0 & 1 & 3 & 7 & 6 & 2 & 5 & 1 & 2 & 0 & 0 & 0 & 0 & 1 & 0 & 0 \\
\hline & Neg-cl.-vb & 0 & 4 & 4 & 2 & 5 & 7 & 12 & 6 & 0 & 0 & 10 & 7 & 2 & 4 & 7 & 4 \\
\hline & Total & 0 & 5 & 7 & 9 & 11 & 9 & 17 & 7 & 2 & 0 & 10 & 7 & 2 & 5 & 7 & 4 \\
\hline & $\%$ Interp. & 0 & 0,20 & 0,43 & 0,77 & 0,54 & 0,22 & 0,29 & & 1 & 0 & 0 & 0 & 0 & 0,20 & 0 & 0 \\
\hline \multirow{4}{*}{ Oração } & Cl-neg-vb & 1 & 0 & 1 & 0 & 0 & 1 & 1 & 0 & 1 & 1 & 0 & 0 & 0 & 0 & 0 & 0 \\
\hline & Neg-cl.-vb & 2 & 6 & 4 & 7 & 3 & 13 & 13 & 11 & 1 & 2 & 7 & 4 & 5 & 8 & 6 & 5 \\
\hline & Total & 3 & 6 & 5 & 7 & 3 & 14 & 14 & 11 & 2 & 3 & 7 & 4 & 5 & 8 & 6 & 5 \\
\hline & $\%$ Interp. & 0,33 & 0 & 0,20 & 0 & 0 & 0,07 & 0,07 & 0 & 0,50 & 0,33 & 0 & 0 & 0 & 0 & 0 & 0 \\
\hline \multirow{4}{*}{ Conj-cl } & Cl-neg-vb & 1 & 0 & 0 & 0 & 0 & 0 & 0 & 0 & 1 & 0 & 0 & 0 & 0 & 0 & 0 & 0 \\
\hline & Neg-cl.-vb & 2 & - & - & - & - & - & - & 0 & 3 & 0 & - & - & - & - & - & - \\
\hline & Total & 3 & - & - & - & - & - & - & 0 & 4 & 0 & - & - & - & - & - & - \\
\hline & $\%$ Interp. & 0,33 & 0 & 0 & 0 & 0 & 0 & 0 & 0 & 0,25 & 0 & 0 & 0 & 0 & 0 & 0 & 0 \\
\hline \multirow{4}{*}{ TOTAL } & Cl-neg-vb & 4 & 1 & 9 & 9 & 10 & 4 & 8 & 1 & 4 & 2 & 0 & 0 & 0 & 1 & 1 & 0 \\
\hline & Neg-cl.-vb & 8 & 12 & 11 & 13 & 17 & 26 & 26 & 19 & 5 & 5 & 72 & 23 & 11 & 23 & 25 & 14 \\
\hline & Total & 12 & 13 & 20 & 22 & 27 & 30 & 34 & 20 & 9 & & & & & & & \\
\hline & \% Interp. & 0,33 & 0,08 & 0,81 & 0,69 & 0,58 & 0,15 & 0,30 & 0,05 & 0,44 & 0,29 & 0 & 0 & 0 & 0,04 & 0,04 & 0 \\
\hline
\end{tabular}




\section{iii) Interpolação em orações Coordenadas}

As Conjunções coordenativas que, porque, pois e $o u^{11}$ não são elementos que formam um contexto de interpolação no corpus de Martins. No entanto Ogando 1980 atestou 1 caso de interpolação em uma oração introduzida pela conjunção coordenativa "pois" que Martins diz ser aparente exceção à regra:

“(324) [e] er saben que sempre vos servi / o melhor que pud' e souby cuydar / e por en fazedes de me matar / mal poys vol' eu, senhor, non mereci (Ogando 1980:281)” (Martins 1994:186)

Martins tenta explicar a existência de interpolação nesse caso pela instabilidade dos conectivos referida por Mattos e Silva (1989). Sugere que a oração poderia ser interpretada como subordinada, ou, jogando com a possível ambigüidade do conectivo “pois”, o autor do verso opta pela ordem de palavras estilisticamente mais conveniente.

“... está em causa o carácter coordenativo ou subordinativo da oração em que ocorre o clítico anteposto. O conector "pois" podia estabelecer, entre outras, uma relação de coordenação explicativa ou uma relação de subordinção casual. Interpreto a oração como coordenada. Mas a distinção entre as duas situações nem sempre está isenta de ambigüidade.” (Martins 1994:186,187)

A interpolação da negação no PM é freqüente em orações coordenadas introduzidas pelos conectivos que, porque, pois e ou.

50. Logo certo é que o ouro ama o cobiçoso, e não já o que com êle se compra; pois o não quere para comprar, senão para o possuir. (LOBO XVI)

51. “... minino, por fácil e fagueiro; fermoso, porque a beleza é o objeito dos amantes; despido, porque se não pode encobrir; ..." (LOBO - XVI)

52. Meu compadre é meu compadre, ou não sei ou me não atrevo a defini-lo por outros têrmos. (Melo - XVII)

53. À fé, que me não descontenta a rosca que tirou para si aquele Ministro esta festa. (Melo - XVII)

\section{Quadro VII}

\begin{tabular}{|l|c|c|c|c|c|c|c|c|c|c|c|c|c|c|c|l|}
\hline & Couto & Sousa & Lobo & Melo & Vie-c & Vie-s & Chag & Bern & Broch & A-Bar & Aires & Vern & Garc & Alor & Gatt & Ortig \\
\hline Data & 1542 & 1556 & 1579 & 1608 & 1608 & 1608 & 1631 & 1644 & 1651 & 1675 & 1705 & 1713 & 1724 & 1750 & 1799 & 1836 \\
\hline Cl-neg-V & 9 & 2 & 9 & 9 & 7 & 4 & 13 & 5 & 0 & 0 & 4 & 2 & 5 & 0 & 4 & 0 \\
\hline Neg-cl-V & 4 & 5 & 2 & 6 & 3 & 6 & 9 & 4 & 4 & 1 & 6 & 17 & 2 & 2 & 0 & 1 \\
\hline Total & 13 & 7 & 11 & 15 & 10 & 10 & 22 & 9 & 4 & 1 & 10 & 19 & 7 & 2 & 4 & 1 \\
\hline \%clnegV & 0,69 & 0,29 & 0,82 & 0,60 & 0,70 & 0,40 & 0,59 & 0,56 & 0,00 & 0,00 & 0,40 & 0,11 & 0,71 & 0,00 & 1,00 & 0,00 \\
\hline \%negclV & 0,31 & 0,71 & 0,18 & 0,40 & 0,30 & 0,60 & 0,41 & 0,44 & 1,00 & 1,00 & 0,60 & 0,89 & 0,29 & 1,00 & 0,00 & 1,00 \\
\hline
\end{tabular}

${ }^{11}$ Conjunções coordenativas introduzidas pelas conjunções diferentes de "e" e "mas" - as coordenadas aditivas e adversativas, por comportarem-se de maneira bastante semelhante às orações matrizes, no que diz respeito ao clítico, foram agrupadas às orações não dependentes. 
NAMIUTI - Um estudo sobre o fenômeno da interpolação...

Atestei também 1 caso de interpolação da negação em uma oração coordenada com entretanto:

54. Retenho os papeis emquanto Vossa Mercê me avisa e tambem entretanto os não faço copiar. (Melo - XVII)

\section{CONSTITUINTES QUE ANTECEDEM LINEARMENTE AS ESTRUTURAS COM INTERPOLAÇÃO. A CONTIGÜIDADE DO CLÍTICO AO CONECTIVO.}

No corpus de Martins, na quase totalidade dos casos de interpolação, o clítico é imediatamente adjacente ao elemento que introduz a oração e que condiciona a próclise, quer se trate de uma conjunção subordinativa ou um pronome relativo (em orações subordinadas finitas); de uma preposição (em orações subordinadas infinitivas), ou de um advérbio, quantificador ou sintagma focalizado (nas orações não dependentes). Somente em orações subordinadas finitas o clítico pode ocorrer separado quer do verbo quer do elemento que determina próclise, indicando que a contigüidade entre o operador e o clítico não é obrigatória, podendo ocorrer um sintagma nominal (sujeito ou objeto), preposicional ou adverbial. Isso porém acontece raramente. Martins destaca uma passagem de Mattos e Silva (1989) onde considera que os enunciados subordinados, além de próclise constante, são caracterizados por contigüidade do pronome complemento ao elemento subordinante na grande maioria dos casos. Esta seria, segundo essa autora, a razão pela qual a interpolação é preferida no período medieval, pois quando ocorrem outros elementos, em geral, eles se intercalam entre o pronome e o verbo a fim de manter a contiguidade do operador com o clítico.

O quadro VIII abaixo mostra a preferência à contigüidade do operador subordinativo (C) e do clítico nos dados de Martins:

Quadro-VIII: dados de Martins PA

\begin{tabular}{|l|l|}
\hline C-cl-x-V & $\begin{array}{l}309 \\
(0,96)\end{array}$ \\
\hline C-y-cl-x-V & $\begin{array}{l}12 \\
(0,04)\end{array}$ \\
\hline Total & 321 \\
\hline
\end{tabular}

Os 12 casos em que Martins atesta a falta de contigüidade estão listados abaixo:

(42) que [ pera esto ] lhe nõ ualhã (Lx, 1440)

(44) e de rreuora que [ cousa alg ua ] lhe nom ficaua $(L x, 1483)$

(47) E durante o tempo das dictas tres pessoas que [ eles emprezadores nem a pessoa depos elles ] o nõ possam engeitar (NO, 1509)

(61) que [ pera ysto] lhes nõ valhão (Lx 1440) 
Cadernos de Estudos Lingüísticos 48(2) - Jul./Dez. 2006

(88) E com todas as pertenças que [ aos dictos casaaes] Ihes dereitam ente pert eçe (NO, 1522)

(89) os quaaes [ Casaaes com todas suas pertenças] lhes asi emprazavam (NO, 1522)

(170) E sse [ pela u etura] uos algu e enbargar $(L x, 1294)$

(172) E sse [ pela u etujra] uos algu e enbargar $(L x, 1296)$

(191) e que [ sempre ] a os Moesteyros de Anssedj e de Arnoya usarõ e possoyrã (NO, 1285)

(224) E sse [ pela u etujra] uos algu e a dicta v ya enbargar (Lx, 1296)

(272) E sse [ pela u etura ] a uos assi nõ adubardes (Lx, 1305)

(273) E sse [ pela uentura ] a uos assi nõ adubardes (Lx, 1305)

Os exemplos de não contiguidade levantados por Martins metade são tardios (século $\mathrm{XV} / \mathrm{XVI}$ ), e dos 6 casos mais antigos (século XIII/XIV) 5 repetem a mesma estrutura: "sse pela u entura".

Nos textos do corpus Tycho Brahe (PC) a contigüidade entre o operador e o clítico deixa de ser preferencial, abrange os contextos não finitos e também os contextos não subordinados (orações coordenadas introduzidas pelas conjunções do tipo que, pois, porque e ou).

Quadro IX: Corpus Tycho Brahe

\begin{tabular}{|c|c|}
\hline Subordinadas finitas & PC \\
\hline C -cl-neg-V & $548(63 \%)$ \\
\hline $\begin{array}{l}\mathrm{C} \text {-y-cl-neg-V } \\
\text { Total }\end{array}$ & $\begin{array}{l}320(375) \\
868\end{array}$ \\
\hline \multicolumn{2}{|l|}{ Coordenadas } \\
\hline conj-cl-neg-V & $50(69 \%)$ \\
\hline conj-y-cl-neg-V & $22(31 \%)$ \\
\hline Total & 72 \\
\hline \multicolumn{2}{|l|}{ Infinitivas } \\
\hline P-cl-neg-V & $102(94 \%)$ \\
\hline $\begin{array}{l}\text { P-y-cl-neg-V } \\
\text { Total }\end{array}$ & $\begin{array}{l}6(6 \%) \\
108\end{array}$ \\
\hline
\end{tabular}

Lembremos que os constituintes que podiam estar intercalados entre o elemento causador da próclise e o clítico no PA, de acordo com Martins, são: um sintagma nominal (sujeito ou objeto), preposicional ou adverbial, desde que estes constituintes sejam "não interpoláveis" (tópico ou outro adjunto frásico e sintagmas focalizados). E somente em subordinadas finitas. Entretanto, novos elementos passam a ocorrer entre "C-cl", e ainda 
NAMIUTI - Um estudo sobre o fenômeno da interpolação...

esta ordem passa a abranger novos contextos: constituintes vários podem ocorrer também entre a preposição e o clítico nas orações infinitivas e entre a conjunção e o clítico nas orações coordenadas:

\section{- Sujeitos interpoláveis:}

55. Isto digo, enquanto Vossa Reverência lhe não der os ditos mil cruzados que disse . (Sousa -XVI)

56. - Boa está a derivação ( tornou o Fidalgo ), porém vamos à brevidade, que $e u$ me não atrevera a culpar se agora vos não ouvira . (Lobo-XVI)

57. Vossa Excelência a ampare com sua humanidade, lembrando-se que, como não pode haver Côrte sem Príncipe, que esta o não podia parecer sem que tivesse por si a Vossa Excelência, e que, como em noites de Inverno , ficara muito às escuras êste livro sem a luz e graça que espera comunicar de sua clareza . (Lobo-XVI)

58. A esta cortesia respondeu Píndaro, e o Estudante com as suas, té que o Doutor os despartiu, e disse a Leonardo : - Bem gastado era o tempo em comprimentos tão cortesãos, e tão devidos, $\underline{\text { se } o \text { desejo que }}$ temos de continuar a matéria da noite passada o não quisera poupar todo para ela; e assim vos peço que me façais mercê, e a todos, de ir por diante . (Lobo-XVI)

59. O padre Pontilier beija a mão a Vossa Excelência muitas vezes, sentido de Vossa Excelência lhe não mandar aquelas novas de Lisboa : não escreve, porque prègou hontem, e préga dia de Natal e a primeira e segunda oitava, e todas as mais vezes que o quizerem ouvir, e creia-me Vossa Excelência que é grande prègador . (Vieira-cartas-XVII)

60. De maneira que , quando França cuidou que a paz de Portugal com Holanda podia ser causa de Holanda se não unir com Castela , quis alcançar esta desunião a preço de uma praça nossa , tão importante como a Baía ; e agora que Holanda se uniu com Castela , querem que fique também em guerra connosco , para que nós ajudemos a lhe quebrantar as fôrças, e gaste Holanda contra Portugal o com que podia socorrer aos castelhanos . (Vieira-cartas-XVII)

61. Dá agora conta de tantas inspirações interiores minhas, de tantos conselhos dos professores e amigos, de tantas vozes e ameaças dos prégadores, que ou não querias ouvir, ou ouvias por curiosidade e cerimonia; e tambem t'a podera pedir, de eu mesmo te não chamar efficazmente na hora da morte, porque o desmereceste na vida. (Vieira-sermões-XVII)

\section{- Sintagmas Advérbiais preposicionais e orações:}

62. E o tempo descobriu logo que não somente se não enganara, mas que fora um antever de alto entendimento. (Sousa-XVI)

63. E assim não me desagradou outra, que dizia desta maneira: “Com os tempos contrários à navegação o foram as ocasiões ao nosso trato; que, como as mercadorias não foram requestadas de estrangeiros, estão ao presente abatidas; enviai-me menos delas para que, faltando, mais as procurem os mercadores da terra; $\underline{\text { e }}$ nessa vos não descuideis de fazer emprêgo, mandando-me o de muito boas novas vossas". (Lobo-XVI)

64. Entrando depois em casa de seu pai, nem a ela, nem a êle conhecia, polo diferente estado em que a deixara; e, como nesta mudança se lhe não aquietava o coração, foise com muita pressa aonde o tinha pôsto. (Lobo-XVI)

65. Há-de ser animoso e liberal; o primeiro, por que nas matérias que tocarem a guerra, trégua e liga, ou confederação com o seu Príncipe, se não mostre por sua parte acanhado, tímido, nem pusilânimo; antes obrigue com seu exemplo a que o respeitem e temam, e também por que, na ocasião em que se oferecer ao senhor a quem assiste, 
acredite com o conselho e com as obras às armas de seus ascendentes e naturais. (Lobo-XVI)

66. Para em Calais me não impedirem a saída, nem nas outras cidades até Paris me negarem a entrada por ir de lugar infecto, levo passaporte e recomendação do embaixador de França que está neste reino, o qual também me remeteu os maços das embaixadas debaixo dos seus, que foi maior segurança com que se podiam enviar; e a tudo o mais do serviço de Sua Majestade se ofereceu com boa vontade. (Vieira-cartas-XVII)

67. Mas posso certificar a Vossa Mercê que já antes tive assaz de sentimento, porque havendo-me Ene cometido o historiar a vida do senhor Ene seu pai, me não deixou liberdade para que eu pudesse escrevê-la em nossa língua. (Melo-XVII)

68. Todas passaram como a náu, que vae cortando as ondas, e depois que passou, se lhe não acha rasto: Et tanquam navis , quæ pertransit fluctuantem aquam; cujus, cum præterierit, non est vestigium invenire. (Vieira-sermões-XVII)

\section{- Sintagmas e orações apositivas}

69. Aceitou finalmente, à pura força de obediência, que é um dos três votos essenciais e solenes de todo religioso que, sem pecado, se não podem quebrar. (Sousa -XVI)

70. Que, na verdade, me não maravilha pouco que, sendo o principal instituto dela o exercício das Letras e prudentíssimo o instituidor, não haja cousa , na regra que nos deixou, que ao parecer de muitos não encontre e desfavoreça o mesmo exercício : o coro contínuo - e coro cantado - e repartido polas horas do dia e noite que mais quebrantam a humanidade: o jejum de sete meses; o peixe de todo o ano. (Sousa-XVI)

71. Juntamente assentámos dar-vos êste aviso, por que, se alguma cousa acontecer, se não presuma que saíu do nosso conselho; e, não sendo o intento dêle pelejar por preço, prémio ou engano, vós, à falta de cautela, percais a vida“. (Lobo-XVI)

72. Dai-me razão de vós, que já passais de sete anos : já podeis ter uso dela, salvo se , do muito que a usastes, a não tendes já. (Melo-XVII)

73. - O meu voto ( tornou Feliciano ) é de pouca importância e o lugar, devido a outrem; mas com tôda a humildade aceitarei o que me derem; e se com a minha razão ficar corrido, barato é o saber que se compra com primeiro errar; e assim digo que os encarecimentos nacidos de amor não devem parecer estranhos ( por desiguais que sejam ) a nenhum juízo afeiçoado; porque o amante, para pintar a fermosura de uma dama que satisfaz a seus olhos e pensamentos, dificultosamente achará nas cousas criadas a que a compare que lhe fique parecendo que a encarece; porque, ainda que sejam fermosas as estrêlas, lhe não agradam tanto como os seus olhos; e sendo o Sol tão belo, se alegra menos com a claridade de sua luz que com ver o rosto de quem ama ; ... (Lobo-XVI)

74. Passa já de vinte dias que subiu a minha consulta; já pudera beixar, se , pelo amor que me tem Ene, se não ficou com ela. (Lobo-XVI)

75. Do sentir fazemos nosso ofício aquele que nos compete; porque se, como sensitivos, nos não desobrigamos de sentir, como racionais somos obrigados a temperar o sentimento com a paciência, a paixão com o valor, a pena com a esperança. (Melo-XVII)

76. Hontem escreveu Lopo Ramires ao senhor Embaixador que, a causa disto , se não achava em Amsterdam quem quisesse passar um vintém para Lisboa . (Vieira-cartas-XVI)

\section{- Mais de um constituinte}

77. Pois, ainda que eu sou Bacharel em linguagem, me atrevo a contradizer essa opinião adquerida em Latim: porque para recreação, polícia e bom estilo se não deve menor lugar a êstes que aos vossos de trapaças e opiniões, e outros a que chamais conselhos, que o dão às vezes bem ruim a quem se fia de sua leitura . (Lobo-XVI) 
NAMIUTI - Um estudo sobre o fenômeno da interpolação...

78. -/(A mi me parece bem ( disse Solino ) a razão do Licenciado, que o Doutor tinha jeito de meter os louvores de uma dama em exemplos caseiros, chamando-lhe fresca como o seu pomar, linda como o seu jardim , clara como a sua fonte e alta como as suas faias ; e como os amantes, para encarecer, se não contentam com pouco, todos chegam ao que pode ser: todo o branco é cristal e diamantes; o còrado , rosas e rubis; o verde, esmeraldas; o azul, safiras, e o amarelo, ouro e jacintos; e até as mães dos mininos, a que naturalmente têm excessiva amor, não lhes sabem chamar pouco: quando os tomam nos braços, logo os intitulam de meu duque, meu marquês, meu conde; nas pedras, meu diamante, e, nas flôres , meu cravo e minha rosa; quanto mais louvando mulheres, a quem todo o encarecimento fica curto e envergonhado pola fôrça com que têm cativos os sentidos e as potências dos que hão-de falar nelas. (Lobo-XVI)

79. Nada disto será perfeito, se Vossa Senhoria, sendo-lhe possível, se não puser a coroar com seu valor esta obra, procurando-me algumas cartas do Príncipe de Oranje e dos Estados, que em favor meu recomendem minha causa; cousa que não julgo impossível; e mais sendo Vossa Senhoria o instrumento, havendo-se já feito para apadrinhar sujeitos de mui diferentes qualidades. (Melo-XVII)

O quadro $\mathrm{X}$ abaixo retrata a frequiência do uso das estruturas com e sem contigüidade entre o complementador e o clítico em orações subordinadas finitas nos textos dos autores do corpus Tycho Brahe:

\section{Quadro X: Orações Subordinadas finitas (na próxima página)}

Também em orações coordenadas pelos conectivos que, pois o clítico não está obrigatoriamente adjacente ao conectivo em estruturas com interpolação de "não".

\section{Quadro XI: Orações coordenadas (na próxima página)}

Nas orações infinitivas atestamos uma preferência pela adjacência à preposição nos textos do corpus. Apenas 6 casos de interpolação da negação em todo o corpus que tomo têm o clítico não adjacente à preposição. Só no texto de Diogo do Couto há 3 ocorrências, os outros 3 dados são de textos do século 17, e ainda, todos de António Vieira com a preposição "de", 2 nas cartas e 1 nos sermões.

81. Feito isto, poz ali Capitão novo, e o mesmo fez em tôdas as fortalezas, e tanadarias de Concan, reduzindo-o outra vez à Coroa do Reino, porque o tinha dado ao Accedecan, determinando de mais o não dar a pessoa particular, por se não fazer poderoso, arrendando suas terras, aldêas, e pondo outras cousas em ordem. (Couto-XVI)

\section{CONSIDERAÇÕES FINAIS}

Vimos que a interpolação dos elementos do sintagma verbal está em vias de desaparecer por completo já no século 16 (os autores nascidos neste século apresentam apenas resquícios desta interpolação). Neste mesmo século encontramos um padrão proclítico nas orações não dependentes neutras afirmativas (cf. Paixão de Sousa 2004, Galves/Britto/e Paixão de Sousa 2005, entre outros trabalhos). Coincidentemente, há um aumento nas sentenças subordinadas com elementos entre o conectivo e o clítico: notei que a não adjacência entre 
Quadro X: Orações Subordinadas finitas

\begin{tabular}{|c|c|c|c|c|c|c|c|c|c|c|c|c|c|c|c|c|}
\hline & Couto & Sousa & Lobo & Melo & Vie-c & Vie-s & Chag & Bern & Broch & A-Bar & Aires & Vern & Garc & Alor & Gatt & Ortig \\
\hline Data & 1542 & 1556 & 1579 & 1608 & 1608 & 1608 & 1631 & 1644 & 1651 & 1675 & 1705 & 1713 & 1724 & 1750 & 1799 & 1836 \\
\hline Contíguas & 38 & 32 & 36 & 51 & 60 & 49 & 49 & 31 & 17 & 11 & 56 & 22 & 10 & 29 & 37 & 20 \\
\hline não contíguas & 17 & 10 & 25 & 35 & 49 & 24 & 39 & 17 & 13 & 7 & 20 & 5 & 9 & 24 & 16 & 10 \\
\hline Total & 55 & 42 & 61 & 86 & 109 & 73 & 88 & 48 & 30 & 18 & 76 & 27 & 19 & 53 & 53 & 30 \\
\hline $\begin{array}{l}\text { \%operador-cl- } \\
\text {-neg-V }\end{array}$ & 0,69 & 0,76 & 0,59 & 0,59 & 0,55 & 0,67 & 0,56 & 0,65 & 0,57 & 0,61 & 0,74 & 0,81 & 0,53 & 0,55 & 0,70 & 0,67 \\
\hline \%operador-X--cl-neg-V & 0,31 & 0,24 & 0,41 & 0,41 & 0,45 & 0,33 & 0,44 & 0,35 & 0,43 & 0,39 & 0,26 & 0,19 & 0,47 & 0,45 & 0,30 & 0,33 \\
\hline
\end{tabular}

Quadro XI: Orações coordenadas

\begin{tabular}{|c|c|c|c|c|c|c|c|c|c|c|c|c|c|c|c|c|}
\hline & Couto & Sousa & Lobo & Melo & Vie-c & Vie-s & Chag & Bern & Broch & A-Bar & Aires & Vern & Garc & Alor & Gatt & Ortig \\
\hline Data & 1542 & 1556 & 1579 & 1608 & 1608 & 1608 & 1631 & 1644 & 1651 & 1675 & 1705 & 1713 & 1724 & 1750 & 1799 & 1836 \\
\hline CONJ-cl-neg-V & 7 & 1 & 4 & 8 & 3 & 3 & 8 & 4 & 0 & 0 & 4 & 2 & 3 & 0 & 3 & 0 \\
\hline CONJ-X-cl-neg-V & 2 & 1 & 5 & 1 & 4 & 1 & 5 & 1 & 0 & 0 & 0 & 0 & 1 & 0 & 1 & 0 \\
\hline Total & 9 & 2 & 9 & 9 & 7 & 4 & 13 & 5 & 0 & $\mathbf{0}$ & 4 & 2 & 4 & $\mathbf{0}$ & 4 & $\mathbf{0}$ \\
\hline$\% \mathrm{CONJ}-\mathrm{x}-\mathrm{cl}-\mathrm{-neg}-\mathrm{V}$ & 0,22 & 0,5 & 0,56 & 0,11 & 0,57 & 0,25 & 0,38 & 0,20 & \# & \# & 0,00 & 0,00 & 0,25 & 0,00 & 0,25 & 0,00 \\
\hline$\% \mathrm{CONJ}-\mathrm{cl}-\mathrm{neg}-\mathrm{V}$ & 0,78 & 0,5 & 0,44 & 0,89 & 0,43 & 0,75 & 0,62 & 0,80 & \# & \# & 1,00 & 1,00 & 0,75 & 0,00 & 0,75 & 0,00 \\
\hline
\end{tabular}


NAMIUTI - Um estudo sobre o fenômeno da interpolação...

o complementizador e o clítico se torna mais comum, o que pode indicar que a ordem ' $\mathrm{C}$ cl-X-(neg)V' (ex.: “e certo que se lhe ElRei não mandára sucessor (Couto_1548)”) abre espaço, neste momento, para a ordem 'C-X-cl-(neg)V' (ex.: “que até o Prior dos Agostinhos , seu Confessor, o não pôde sofrer (Couto_1548)” ).

No que diz respeito à interpolação da negação, não só continua a ser freqüentemente atestada, como abrange novos contextos: orações raízes neutras e infinitivas introduzidas por preposições que não condicionavam a próclise categórica, como a preposição 'em' (ambientes de anteposição opcional do clítico).

As primeiras ocorrências de interpolação da negação encontradas em orações não dependentes neutras foram atestadas por Martins (1994) no final do século 15. Martins, entretanto, não considerou que estes casos de interpolação da negação pudessem compor o reflexo de uma mudança. Todavia a autora reconhece que tais dados, devido à delimitação temporal em que foram atestados, poderiam ser enquadrados em um grupo coeso, e, deste modo refletirem algo novo na gramática desta língua. Esta diferente possibilidade de interpolar a negação mostrou-se freqüente nos textos do corpus Tycho Brahe identificando um grupo coeso de fato.

Como Martins, penso que a possibilidade de interpolar o "não" nestes casos tem a ver com a sintaxe da negação, mas contrariamente a Martins, acredito que o fato de só encontrarmos a interpolação da negação nestes contextos a partir dos textos escritos no final do século 15 seja o reflexo da mudança gramatical que vedou a possibilidade de interpolação dos outros constituintes do sintagma verbal e favoreceu o uso da próclise sobre a ênclise.

É de se esperar que a perda da possibilidade de interpolação nas orações dependentes esteja relacionada com a mudança do padrão enclítico para o padrão proclítico nas orações matrizes, provavelmente ocasionadas por uma reanálise qualquer do clítico. Isto é o que acontece em todas as línguas românicas que exibiam estes padrões: todas perderam a ênclise e também o fenômeno da interpolação, existentes nas fases antigas (cf. Rivero 1997, Fontana 1997, Salve 1991 entre muitos outros trabalhos) dando lugar à próclise verbal.

Esta visão sobre os dados é um tanto diferente da visão delineada a partir de Martins (1994) que considera que a perda da possibilidade de interpolação nos domínios encaixados está diretamente relacionada com a perda da possibilidade da próclise nas orações raízes neutras na história do Português Europeu, esta mudança conecta diretamente a gramática que gera o fenômeno da interpolação (ex.: “.... como se nesta carta contem ...” NO, 1538. Martins 1994), característico do português arcaico, à gramática do português europeu moderno que exibe um padrão enclítico nas orações raízes neutras (ex. "O Paulo faloume").

O que quero sugerir aqui, a partir da descrição dos dados apresentada no artigo, é em partes o contrário do que afirma Martins, para mim a perda da possibilidade da interpolação não corresponde à mesma mudança que veda a possibilidade da próclise nas orações raízes neutras. A comparação com os padrões de colocação pronominal nos ambientes negativos pode corroborar a hipótese de um estado gramatical intermediário entre PA e PE. 


\section{REFERÊNCIAS BIBLIOGRÁFICAS}

ABDO, P. L. (2000) - Colocação de Clíticos em orações Infinitivas introduzidas por Preposição no Português Clássico. Projeto de iniciação científica - Relatório final, 2000 (fapesp).

FONTANA, Josep M. (1997). "On the integration of second position phenomena". Em: Parameters of Morphosyntatic Change, ed. Ans van Kemenade \& Nigel Vicenti, 207 - 249. Cambridge University Press.

GALVES, C. et alii (1998) Padrões Rítmicos, Fixação de Parâmetros e Mudança Lingüística. UNICAMP CAMPINAS. (Projeto de pesquisa FAPESP) . (2001). Ensaios sobre as Gramáticas do Português. Campinas. São Paulo. Editora da Unicamp. . (2004). Padrões Rítmicos, Fixação de Parâmetros e Mudança Lingüística - Fase II. UNICAMP CAMPINAS. (Projeto de pesquisa FAPESP)

GALVES, Charlotte, BRITTO, Helena e PAIXÃO DE SOUSA, Maria Clara (2005) - "Clitic Placement in Europena Portuguese: Results from the Tycho Brahe Corpus". Em: Journal of Portuguese Linguistics, Vol $4, n .1$, Special Issue on variation and change in the Iberian languages: the Peninsula and beyond. No prelo.

GALVES, Charlotte, NAMIUTI, Cristiane e PAIXÃO DE SOUSA, Maria Clara (2006) - "Novas perspectivas para antigas questões: revisitando a periodização da língua portuguesa". Em: Grammatische Structuren des Europäischen Portugiesisch. Annette Endruschat / Rolf Kemmler / Bárbara Schäfer-PrieB (Hrsg). Turbigen: Calapinus Verlag, págs 45-75.

KROCH, A. (1989). "Reflexes of grammar in patterns of language change". Em: Language Variation and Change 199-244. Cambridge University Press.

. (2003). "Mudança sintática". Em: http://www.ling.upenn.edu/ kroch. Traduzido por Silvia Cavalcante.

MARTINS, A.M. (1994) - Clíticos na história do português. Dissertação de Doutorado. Lisboa, Universidade de Lisboa (mimeo).

NAMIUTI, Cristiane. (2002). "Interpolação no português clássico", em: Massini-Cagliari, Gladis (Org.) (2002): Anais do II Encontro de Estudos Diacrônicos do Português, Araraquara: FCL/UNESP; Universidade de Évora, págs. 211-219.

. (em curso): Interpolação, colocação de clíticos e mudança gramatical na história do português europeu. Tese de Doutoramento em curso.

PAIXÃO, M. C. (2004) - Língua Barroca: Sintaxe e História do português nos 1600. Dissertação de Doutorado. Campinas. UNICAMP.

PARCERO, L. M de J. (1999) - Fronteamentos de Constituintes no Português dos séculos XV, XVI e XVII. Dissertação apresentada como requisito parcial para a obtenção do Curso de Mestrado

RIBEIRO, Ilza. (1995). A sintaxe da ordem do português arcaico: o efeito V2. . Tese de Doutoramento, Instituto de Estudos da Linguagem, Universidade Estadual de Campinas.

RIVERO, Maria Luiza. (1986). "La tipologia de los pronombres átonos em el espãñol medieval y em español actual". Em: Anuário de Lingüística Hispânica II, 197-220.

. (1997) - "On two locations for complement clitic pronouns: Serbo-Croatian, Bulgarian and Old Spanish". Em: A. Van Kemenade, N. Vicenti (orgs): Parameters of morphosyntatic change. Cambridge University Press. 
NAMIUTI - Um estudo sobre o fenômeno da interpolação...

SALVI, Gianpolo. (1991). " Difesa e illustrazione della legge di Wackernagel applicata alle lingue romanze antiche: La pozicione delle forme pronominali clitiche”. Em, por Giovan Battista Pellegrine: Scritti degli allievi padovani, 439 - 462. Padova: Unipress.

\section{O CORPUS:}

Diogo do Couto (1542-1606) - Décadas (selecção, prefácio e notas de António Baião). Vol 1. Lisboa, Livraria Sá da Costa - Editora, 1947.

Luís de Sousa (1556-1632) Vida de Dom Frei Bertolameu dos Mártires (ed. Aníbal Pinto de Castro \& Gladstone Chaves de Melo). Lisboa, Imprensa Nacional - Casa da Moeda, 1984. - 53,928 palavras

Francisco Rodrigues Lobo (1574-1621) Corte na Aldeia e Noites de Inverno (prefácio e notas de Afonso Lopes Vieira). Lisboa, Livraria Sá da Costa - Editora, 1927. - 52,429 palavras

Francisco Manuel de Melo (1608-1666) Cartas Familiares (selecção, prefácio e notas pelo Prof. Rodrigues Lapa). Lisboa, Livraria Sá da Costa - Editora, 1937. 58,070 words

António Vieira (1608-1697) Cartas (ed. Lúcio d'Azevedo). Coimbra, Imprensa da Universidade, 1925. 57,088 palavras

António Vieira (1608-1697) Sermões (ed. prefaciada e revista pelo Rev. Padre Gonçalo Alves). Porto, Livraria Chardon, de Lello \& Irmão Editores. - 53,855 palavras

António das Chagas (1631-1682) Cartas Espirituais (ed. Rodrigues Lapa). Lisboa, Livraria Sá da Costa Editora. - 54,445 palavras

Manuel Bernardes (1644-1710) Nova Floresta (introdução de Alberto L. Rodrigues). Porto, Lello \& Irmão Editores, 1974.

José da Cunha Brochado (1651-1735) Cartas (selecção, prefácio e notas de Antònio Álvaro Dória). Lisboa, Editora Livraria Sá da Costa, 1944.

André de Barros (1675-1754) Vida do Apostolico Padre António Vieira. Officina Sylviana. Lisboa. 1746

Matias Aires (1705-1763) Reflexães sobre a Vaidade dos Homens ou Discursos Moraes. Lisboa, Imprensa Nacional - Casa da Moeda, 1980. 56,479 palavras

Luís António Verney (1713-1792) Verdadeiro Método de Estudar (ed. António Salgado Filho). Lisboa, Livraria Sá da Costa - Editora, 1949. - 49,335 palavras

Marquesa d'Alorna (1750-1839) Inéditos, Cartas e Outros Escritos (ed. Hernani Cidade). Lisboa, Livraria Sá da Costa Editora, 1941. - 49,512 palavras

Correia Garção (1724-1772). Obras Completas (texto fixado, prefácio e notas por António José Saraiva). Volume II, Prosas e Teatro. Lisboa, Livraria Sá da Costa, 1982. - 24,924 palavras

Almeida Garrett (1799-1854) Viagens na Minha Terra (electronic edition - CD-ROM - Biblioteca Virtual de Autores Portugueses). Lisboa, Imprensa Nacional - Biblioteca Nacional, 1998- 51,784 palavras

Ramalho Ortigão (1836-1915) Cartas a Emília. (Introdução, fixação do texto, comentários e notas de Beatriz Berrini). Lisboa, Lisóptima Edições - Biblioteca Nacional, 1993. - 32,441 palavras. 